\title{
An Evaluation of Response to Therapy in Patients Undergoing Radiotherapy or Surgery in the Treatment of Prostate Cancer
}

\author{
Prostat Kanserinin Tedavisinde Radyoterapi veya Cerrahi Yapılmış \\ Hastalarda Tedaviye Yanıt Değerlendirilmesi
}

\author{
Abdulsemet ZORTUL $\odot$, Hilal KIZILTUNC OZMEN ๑, Saban Oguz DEMIRDOGEN ๑
}

Ethics Committee Approval: This study approved by the Ataturk University Clinical Studies Ethic Committee, 8 December 2016, 2016/22.

Conflict of interest: The authors declare that they have no conflict of interest.

Funding: None.

Informed Consent: Not Applicable.
Cite as: Zortul A, Kiziltunc Ozmen H, Demirdogen SO. An evaluation of response to therapy in patients undergoing radiotherapy or surgery in the treatment of prostate cancer. Medeniyet Med J. 2019;34:263-70.

\begin{abstract}
Objective: This study compared biochemical recurrence (BR), biochemical recurrence-free survival (BRFS) and overall survival (OS) rates and therapeutic methods in patients undergoing definitive radiotherapy (RT) or radical prostatectomy (RP) because of diagnosis of prostate cancer. Method: Files of 128 patients undergoing $R P(n=82)$ or $R T(n=46)$, who did not receive salvage therapy, and with serum PSA levels monitored three-monthly for at least two years were examined retrospectively. Patients were assigned into low, intermediate and high risk groups based on D'Amico risk classifications. RP was performed in the surgical arm and in the RT arm 70-74 Gy $R T$ were applied using $3 D$ conformal $R T$ technique.

Results: BR was not detected among low risk group patients over 10-year follow-up. No difference was determined between the treatment arms in BR in the intermediate risk patients, while the $R T$ arm was statistically significantly better among the high risk patients $(p=0.04)$. OS rates in the low, intermediate, and high risk groups were $97.1 \%, 93.8 \%$, and $92.3 \%$, respectively, in the $R P$, and $81.8 \%, 92.9 \%$, and $90.5 \%$, respectively, in $R T(p>0.05)$ group. BRFS rates in the intermediate and high risk groups were $92.3 \%$, vs $95.2 \%$ in $R P$, and $79.6 \%$, vs $81.6 \%$ in $R T(p>0.05)$. Conclusion: There was no significant difference between BRFS and OS rates in the two arms of prostate cancer treatment, although $R T$ was better in the high risk group patients in terms of $B R$. Longer-term studies involving high-dose RT techniques applied with maximum protection of normal tissue and supporting the effectiveness of $R T$ are needed.
\end{abstract}

Keywords: Prostatectomy, radiotherapy, prostate cancer

Öz

Amaç: Bu çalışmada prostat kanseri tanısı ile definitif radyoterapi $(R T)$ veya radikal prostatektomi $(R P)$ uygulanmış hastaların biyokimyasal nüks (BN), biyokimyasal nükssüz sağkalım (BNS) ve genel sağkalım (GS) oranları ile tedavi yöntemlerini karşılaştırmayı amaçladık.

Yöntem: $R P(n=82)$ veya $R T(n=46)$ uygulanmış, herhangi bir kurtarma tedavisi uygulanmayan, en az 2 yıl 3 ayda bir serum PSA seviyeleri ile takip edilen 128 hasta dosyası retrospektif olarak tarandı. Hastaların hepsi D'Amico risk sınıflamasına göre düşük, orta ve yüksek risk grubu olarak sınıflandırılmıştı. Cerrahi kolunda radikal prostatektomi yapılmışken, RT koluna 3D konformal RT tekniğinde70-74 Gy RT uygulanmiştı.

Bulgular: 10 yıllık takipte; düşük risk grubu hastalarda BN tespit edilmedi. Orta risk grubu hastalarda BN açısından tedavi kolları arasında fark tespit edilmezken, yüksek risk grubu hastalarda RT kolunun istatistiki olarak anlamlı derecede iyi olduğu saptandı $(p=0.04)$. Düşük, orta ve yüksek risk grubunda GS oranı sirasıly RP'de \%97,1, \%93,8 ve \%92,3 iken; RT'de \%81,8, \%92,9 ve $\% 90,5$ idi $(p>0,05)$. BNS oranları ise orta ve yüksek risk grubunda sırasılyla RP'de \%92,3 ve \%95,2 ve $R T$ 'de $\% 79,6$ ve $\% 81,6$ idi $(p>0,05)$.

Sonuç: Prostat kanseri tedavisinde her iki kolda BNS ve GS oranları arasında anlamlı fark olmayıp, BN oranı açısından yüksek risk grubu hastalarda RT'nindaha iyi olduğu tespit edildi. Sonuç olarak; normal dokuları maksimum seviyede koruyarak uygulayabilen yüksek doz RT teknikleri ile yapıIan ve RT etkinliğini destekleyen daha uzun süreli çalışmalara ihtiyaç vardır.

Anahtar kelimeler: Prostatektomi, radyoterapi, prostat kanseri
Received: 27 June 2019

Accepted: 6 September 2019 Online First: 27 September 2019

Corresponding Author: A. Zortul

ORCID: 0000-0003-2991-5979

Erzurum Regional Training and Research Hospital, Departments of

Radiation Oncology, Erzurum, Turkey

s.zortul27@gmail.com

H. Kiziltunc Ozmen ORCID: 0000-0003-0695-0931

Atatürk University, Departments of Radiation Oncology, Erzurum, Turkey

S.O. Demirdogen ORCID: 0000-0002-8697-8995 Erzurum Regional Training and Research Hospital, Departments of Urology, Erzurum, Turkey 


\section{INTRODUCTION}

Prostate cancer is the most common non-cutaneous cancer in men worldwide, and the second most common in Turkey. It is an important health problem in the elderly male population, particularly in developed countries. Approximately 1.112.000 men were estimated to have been diagnosed with prostate cancer across the world in 2012, and causes death of more than 307.000 cases $^{1-4}$. The prevalence increases with age, and mean age at diagnosis is 70 . The prevalence of prostate cancer under the age of 39 is $1 / 10.000$, rising to $1 / 103$ between the ages of 40 and 59, and to $1 / 8$ between 60 and 79 years. Serum prostate-specific antigen (PSA) levels are being used for screening purposes since 1990s, and advances in imaging techniques, have led to detection of prostate cancer at younger ages and at earlier stages $^{5,6}$. The disease is generally organ-confined at the time of diagnosis, and a very low proportion of cases are determined at a metastatic stage ${ }^{7}$.

Prostate cancer (PCa) is divided into different risk groups based on PSA levels, Gleason score (GS) and tumor stage. PCa can be effectively treated using radical prostatectomy (RP), external beam radiotherapy (EBRT) and/or brachytherapy based on these risk groups ${ }^{7,8}$. Fewer complications in the field of RP have begun being seen due to laparoscopic and robotic techniques with technological advances in recent years 9 . Fewer side-effects in the field of RT are also seen with the increasing spread of intensity-modulated radiotherapy (IMRT), despite a higher RT dose compared to 3-dimensional conformal RT (3DCRT) ${ }^{10,11}$. Factors affecting the form of treatment include life expectancy, comorbid conditions, treatment-related side effects, and the patient's quality of life.

So far several studies have compared RP and RT in terms of effectiveness ${ }^{8,12-17}$. However, the absence of a modern randomized study means that the question of which modality should primarily be applied is still controversial ${ }^{8}$. The form of treat- ment that should be recommended is important, considering the fact that patients diagnosed with prostate cancer are generally elderly and the side effects may develop in association with the treatment.

The purpose of our study was to compare therapeutic efficacy of RT and RP by evaluating the biochemical recurrence (BR), biochemical recurrencefree survival (BRFS) and overall survival (OS) rates in patients with localized prostate cancer who underwent definitive treatments with RT or RP.

\section{MATERIAL and METHODS}

This study approved by the Ataturk University Clinical Studies Ethics Committee, (8 December 2016, 2016/22).

The files of patients presenting to the Ataturk University Medical Faculty Hospital in Turkey, between the years 2005, and 2015, and underwent definitive RT or RP with the diagnosis of prostate cancer were investigated retrospectively. The patients had not received salvage treatment following curative therapy and monitored with PSA levels at three-month intervals for at least two years.

One hundred and twenty-eight patients underwent RP $(n=82)$ or RT $(n=46)$. Patients were divided into low, intermediate, and high risk groups based on the D'Amico risk classification in the light of pre-treatment PSA values, GS, clinical stages, and radiological examinations. Retropubic prostatectomy and/or pelvic lymph node dissection (PLND) was performed on 82 patients and definitive RT on 46 patients. Patients received neoadjuvant, concomitant or adjuvant hormonal therapy (HT) for 6 months in the intermediate risk group ( $n=14)$ and for 24 months in the high risk group. Pre-RT planning was performed by taking cross-sectional images at 5-mm intervals using computerized tomography (CT). A total of 70-74 Gy RT was applied at a dose of 2 Gy/frac- 
tion/day for five days a week over 7-8 weeks using 6-18 MV energy on a linear accelerator (Primus 2000, Germany) device with clinical target volume (CTV), planned target volume (PTV) and organs at risk being determined on the planning system. Routine PSA, complete blood count, and biochemistry tests of the patients were examined before and after treatment in all cases, with follow-up visits performed once every three months in the first two years, and once every six months subsequently.

A post-RP PSA level $\geq 0.2 \mathrm{ng} / \mathrm{ml}$ and a value above $0.2 \mathrm{ng} / \mathrm{ml}$ at subsequent measurements ${ }^{18}$, and PSA rising to $2 \mathrm{ng} / \mathrm{ml}$ or above nadir PSA following RT, with or without $\mathrm{HT}^{19}$ was interpreted as failure of treatment representing $B R$.

BRFS was calculated based on date of recurrence in patients with determined BR from the time of diagnosis, time of death in non-surviving patients, and date of last control in patients for whom information about their latest health status was unavailable. OS was calculated as date of death in subjects dying for any reason after diagnosis, and as date of last control in patients for whom information about their latest health status was unavailable.

\section{Statistical Analysis}

Statistical Package for Social Sciences for Windows 20.0 software was used to analyze the study findings. In addition to descriptive statistical methods (mean, standard deviation, and frequency), Student's t test and one- and two-way ANOVA were used in the analysis of numerical variables, and the chi-square test was used in the analysis of categorical variables. Kaplan Meier analysis was used for survival analysis. Confidence interval was set at $95 \%$ and statistical significance at $\mathrm{p}<0.05$.

\section{RESULTS}

The records of 128 patients who underwent RP $(\mathrm{n}=82)$ or RT $(\mathrm{n}=46)$ due to prostate cancer were examined. The mean duration of follow-up was $45.8 \pm 22.5$ months (24-130), and mean age at diagnosis was $66.5 \pm 7.4$ years (46-86). Mean length of time without BR was $43.2 \pm 21.3$ months (9-80). While $60.6 \%(n=43)$ of patients in RP arm, 39.4\% $(n=28)$ of those in the RT arm were smoking and

Table 1a. Sociodemographic characteristics of patients.

\begin{tabular}{|c|c|c|c|c|}
\hline & & \multicolumn{2}{|c|}{ Treatment type } & \multirow[b]{2}{*}{$\mathbf{p}$} \\
\hline & & $\begin{array}{l}\text { RP } \\
(\mathbf{n}, \%)\end{array}$ & $\begin{array}{l}\text { RT } \\
(\mathbf{n}, \%)\end{array}$ & \\
\hline \multirow[t]{2}{*}{ Smoker } & Yes & $43,60.6$ & $28,39.4$ & $p>0.05$ \\
\hline & No & $39,68.4$ & $18,31.6$ & \\
\hline \multirow[t]{2}{*}{ Consumer alcohol } & Yes & 3,60 & 2,40 & $p>0.05$ \\
\hline & No & $79,64.2$ & $44,35.8$ & \\
\hline \multirow[t]{3}{*}{ PSA (ng/ml) } & $0-10$ & $43,67.2$ & $21,32.8$ & \\
\hline & $10-20$ & $28,73.7$ & $10,26.3$ & $p=0.02^{*}$ \\
\hline & $>20$ & $11,42.3$ & $15,57.7$ & \\
\hline \multirow[t]{4}{*}{ Gleason Skore } & $\leq 6$ & $59,71.1$ & $24,28.9$ & \\
\hline & 7 & $16,55.2$ & $13,44.8$ & $p>0.05$ \\
\hline & $8-10$ & $7,43.8$ & $9,56.2$ & \\
\hline & T1c-T2a & $62,81.6$ & $14,18.4$ & \\
\hline \multirow[t]{2}{*}{ T Staging } & $\mathrm{T} 2 \mathrm{~b}$ & $17,54.8$ & $14,45.2$ & $\mathrm{p}<0.001^{*}$ \\
\hline & $\geq \mathrm{T} 2 \mathrm{c}$ & $3,14.3$ & $18,85.7$ & \\
\hline
\end{tabular}

${ }^{*} p<0.05$ was considered statistically significant, RP: Radical Prostatectomy, RT: Radiotherapy, PSA: Prostate Spesific Antigen

Table $1 \mathrm{~b}$. Sociodemographic characteristics of patients.

\begin{tabular}{llll}
\hline & $\begin{array}{l}\text { RP } \\
\text { (ort. } \pm \text { S.D.) }\end{array}$ & $\begin{array}{l}\text { RT } \\
\text { (ort. } \pm \text { S.D.) }\end{array}$ & P \\
\hline $\begin{array}{l}\text { Mean age at diagnosis } \\
\text { (year) }\end{array}$ & $64.6 \pm 7$ & $69.9 \pm 6.7$ & $\mathrm{p}<0.001^{*}$ \\
$\begin{array}{l}\text { Mean time elapsed } \\
\text { without BR (month) }\end{array}$ & $47.1 \pm 20.5$ & $37.3 \pm 23$ & $\mathrm{p}>0,05$ \\
$\begin{array}{l}\text { Mean duration of } \\
\text { follow-up (month) }\end{array}$ & $46.6 \pm 23$ & $44.3 \pm 21.9$ & $\mathrm{p}>0,05$
\end{tabular}

${ }^{*} p<0.05$ was considered statistically significant, BR: Biochemical Recurrence 
$60 \%(n=3)$ of patients in RP arm, 40\% ( $n=2)$ of patients in RT arm were consuming alcohol. Patients' sociodemographic characteristics are shown in Table 1a,b.

Patients were classified as low risk ( $n=45,35.2 \%)$, intermediate risk ( $n=46,35.9 \%)$, or high risk $(n=37$, 28.9\%) based on the D'Amico risk classification. The low, intermediate, and high risk groups in the RP arm consisted of 34 (41.5\%), 32 (39\%) and 16 (19.5\%) patients, and of 11 (23.9\%), 14 (30.4\%) and $21(45.7 \%)$ in the RT arm, respectively.

Mean ages at diagnosis were $64.6 \pm 7.0$ years in the RP arm and $69.9 \pm 6.7$ in the RT arm, with a statistically significant intergroup difference $(p<0.001)$. Mean age at diagnosis among all patients in the low-risk group was $65.4 \pm 7.0$ years, $63.2 \pm 6.3$ in the RP arm and $72.2 \pm 4.6$ years in the RT arm. Mean age at diagnosis of all patients in the intermediate risk group was $67.1 \pm 8.0$ years, while it was $65.4 \pm 7.8$ years in the RP arm and $71.1 \pm 7.9$ yeras in the RT arm. Mean age at diagnosis among all patients in the high risk group was $66.9 \pm 6.8$ years, while it was $65.7 \pm 7.3$ years in the RP arm and $67.8 \pm 6.5$ years in the RT arm. No significant difference was determined between the two arms.

Mean time elapsed without BR in the low risk group was $49.8 \pm 25.6$ months in the RP arm and $42.1 \pm 19.9$ in the RT arm. Mean time elapsed in the intermediate risk group was $43.8 \pm 23.0$ months in the RP arm and $38 \pm 14.3$ in the RT arm. Mean time elapsed in the high risk group was $41.5 \pm 17.1$ months in the RP arm and $44.7 \pm 25.5$ in the RT arm. No significant difference was determined between the two arms.

As shown in Table 2, examination of all patients' 10-year follow-ups revealed that no BR was determined in the low risk group, but BR was observed in two $(6.2 \%)$ patients in the RP arm and three (21.4\%) patients in the RT arm in the intermediate risk group, although the difference was not sta- tistically significant. BR was determined in seven (43.8\%) patients in the RP arm and three (14.3\%) patients in the RT arm in the high risk group, the difference between the arms was statistically significant $(p<0.05)$.

Table 2. Comparison of treatment types according to risk groups in terms of biochemical recurrence.

\begin{tabular}{|c|c|c|c|c|}
\hline \multirow[b]{2}{*}{ Risk Group } & & \multicolumn{2}{|c|}{ Biochemical Recurrence } & \multirow[b]{2}{*}{$\mathbf{p}$} \\
\hline & & $\begin{array}{l}\text { Yes } \\
\text { n, (\%) }\end{array}$ & $\begin{array}{l}\text { No } \\
\text { n, (\%) }\end{array}$ & \\
\hline \multirow[t]{2}{*}{ Low } & $\mathrm{RP}$ & $0,(0.0)$ & $34,(100)$ & $p>0.05$ \\
\hline & RT & $0,(0.0)$ & $11,(100)$ & \\
\hline \multirow[t]{2}{*}{ Intermediate } & $\mathrm{RP}$ & $2,(6.2)$ & $30,(93.8)$ & $p>0.05$ \\
\hline & RT & $3,(21.4)$ & $11,(78.6)$ & \\
\hline \multirow[t]{2}{*}{ High } & $\mathrm{RP}$ & $7,(43.8)$ & $9,(56.2)$ & $p=0.04^{*}$ \\
\hline & RT & $3,(14.3)$ & $18,(85.7)$ & \\
\hline \multirow[t]{2}{*}{ Total } & $R P$ & $9,(11)$ & $73,(89)$ & $p>0.05$ \\
\hline & RT & $6,(13)$ & $40,(87)$ & \\
\hline
\end{tabular}

${ }^{*} p<0.05$ was considered statistically significant, $R P$ : Radical Prostatectomy, RT: Radiotherapy

Among low-risk patients in the RP arm one patient died from non-prostate malignancy. In the RT arm due causes of death were chronic disease in 2 , and other causes such as accidents in 2 patients.

Among intermediate-risk patients, in the RP arm causes of death were chronic disease in 1 , un-

Table 3. Comparison of death causes according to risk groups in terms of treatment types.

\begin{tabular}{|c|c|c|c|c|}
\hline \multirow[b]{2}{*}{ Risk Group } & \multirow[b]{2}{*}{ Causes of death } & \multicolumn{2}{|c|}{ Treatment type } & \multirow[b]{2}{*}{$\mathbf{p}$} \\
\hline & & $\begin{array}{l}\mathbf{R P} \\
(\mathbf{n}, \%)\end{array}$ & $\begin{array}{l}\text { RT } \\
(\mathbf{n}, \%)\end{array}$ & \\
\hline \multirow[t]{3}{*}{ Low } & $\begin{array}{l}\text { Non-prostatic } \\
\text { malignancies }\end{array}$ & $1,(100)$ & 0 & \\
\hline & Chronic disease & 0 & $2,(100)$ & $p>0,05$ \\
\hline & Other causes & 0 & $2,(100)$ & \\
\hline \multirow[t]{5}{*}{ Intermediate } & Prostate cancer & 0 & $1,(100)$ & \\
\hline & $\begin{array}{l}\text { Non-prostatic } \\
\text { malignancies }\end{array}$ & 0 & $1,(100)$ & \\
\hline & Chronic disease & $1,(50)$ & $1,(50)$ & $p>0,05$ \\
\hline & Other causes & $1,(100)$ & 0 & \\
\hline & Unknown & $1,(100)$ & 0 & \\
\hline \multirow[t]{2}{*}{ High } & Prostate cancer & $1,(33.3)$ & 2,(66.7) & $p>0,05$ \\
\hline & $\begin{array}{l}\text { Non-prostatic } \\
\text { malignancies }\end{array}$ & $1,(50)$ & $1,(50)$ & \\
\hline
\end{tabular}

${ }^{*} p<0.05$ was considered statistically significant, RP: Radical Prostatectomy, RT: Radiotherapy 
known causes in 1, other causes as accidents in 1 patient. in the RT arm 1 patient died from prostate cancer, one from non-prostate malignancy, and one from chronic disease.

Among high-risk patients, in the RP arm causes of death were prostate cancer in 1 , non-prostate malignancy in 1 patients. while two of the patients in the RT arm died from prostate cancer, and one from non-prostate malignancy. No significant differences in terms of causes of death was determined between the arms in the risk groups ( $p>0.05)$ (Table 3).

\section{Overall Survival}

OS analysis in terms of risk groups revealed survival rates of $97.1 \%$, and $81.8 \%$ in patients in the low risk group who underwent RP ant RT, respectively. In the intermediate risk group, OS rates were $93.8 \%$, and $92.9 \%$ in patients who underwent RP and RT, respectively, while in the high

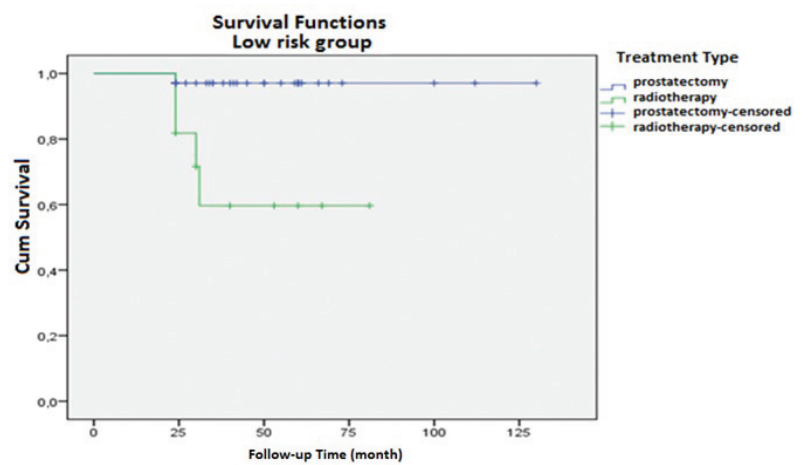

Figure 1. Overall survival according to treatment type in low risk group.

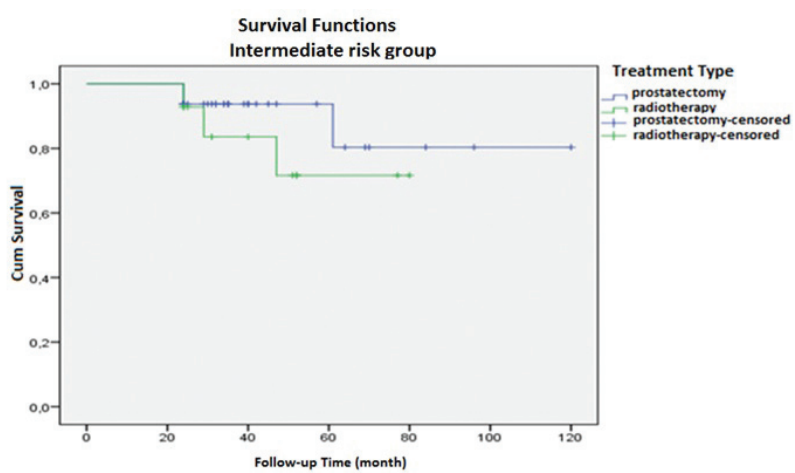

Figure 2. Overall survival according to treatment type in intermediate risk group. risk group OS rates were $92.3 \%$, and $90.6 \%$ in patients who underwent RP and RT, respectively (Figures 1-3). Survival did not reveal analysis any statistically significant differences between groups (logrank p>0.05).

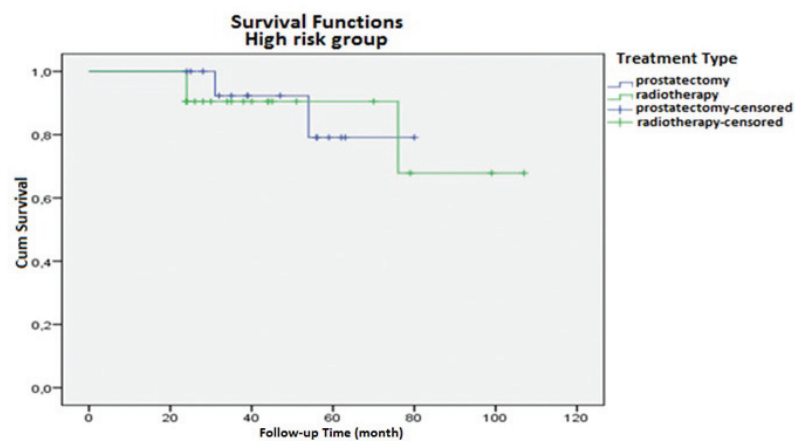

Figure 3. Overall survival according to treatment type in high risk group.

\section{Biochemical recurrence-free survival}

BRFS analysis by risk groups revealed survival rates in the intermediate risk group of $92.3 \%$

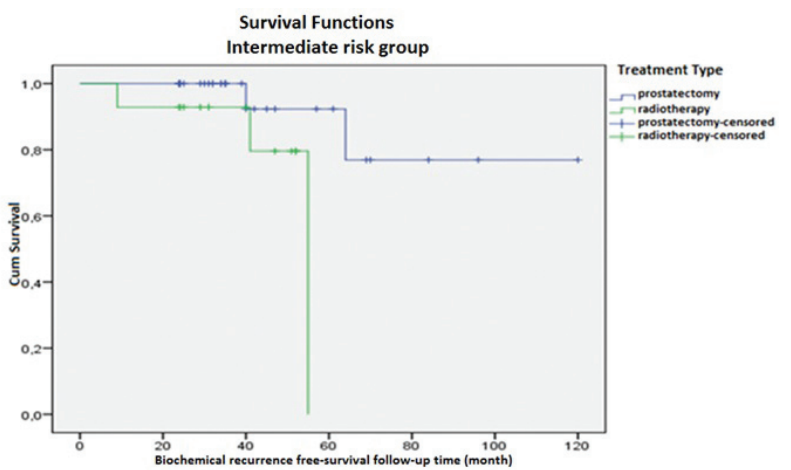

Figure 4. Biochemical recurrence free - survival according to treatment type in intermediate risk group.

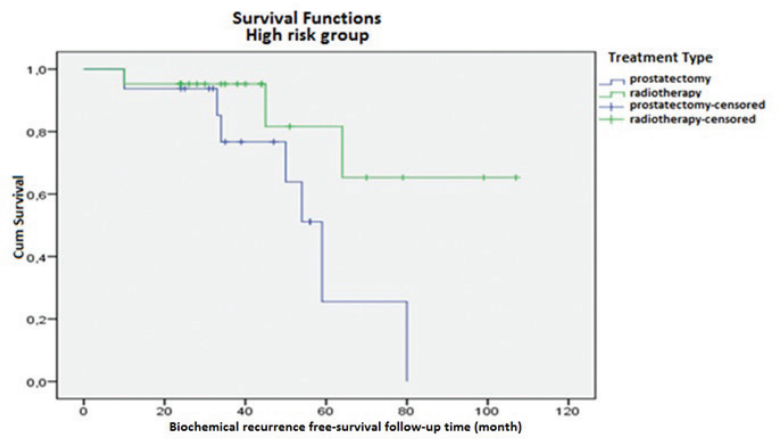

Figure 5. Biochemical recurrence free - survival according to treatment type in high risk group. 
in patients undergoing RP and $79.6 \%$ in those receiving $R T$. In the high risk group, BRFS rates were $95.2 \%$ in patients undergoing RP and $81.6 \%$ of patients receiving RT (Figures 4-5). Any statistically significant difference was not detected between the survival rates (logrank p>0.05).

\section{DISCUSSION}

D'Amico et al. ${ }^{13}$ performed a retrospective investigation of 2635 patients receiving RP and RT. Eight-year BRFS rates were significantly better in the RP arm in the low and favorable intermediate risk group, and no significant difference was determined in terms of types of procedures performed between the unfavorable intermediate risk group and the high risk group. HT was not administered to the patients in that study, and the RT dose was set at $\leq 70.4 \mathrm{~Gy}$. In contrast to that study, we observed no recurrence in either arm in the low risk group, and no statistically significant difference was determined between the arms in the intermediate risk group in terms of number of recurrences or 10-year BRFS rates. However, in the high risk group the RT arm had significantly lower recurrence rates although no significant difference was observed between groups in terms of 10-year BRFS rates.

Aizer et al. ${ }^{14}$ retrospectively examined 556 patients receiving RP and IMRT. They could not find any significant difference in terms of 5-year-BRFS rates between the RP and RT arms in the low and intermediate risk groups, but the RT arm was significantly lower BRFS rates than the RP arm in the high risk group. HT was performed on patients in the RT arm, and the RT dosage was maintained between 72-77.4 Gy. In contrast, we observed no significant difference in terms of BRFS rates between the RP and RT arms in the high risk group. This may be due to the RT dose in our study being limited to 70-74 Gy and to the number of patients investigated retrospectively in our research being considerably lower relative to that study. Simi- lar results to that study might be obtained with a larger patient population and using higher RT doses.

Kupelian et al. ${ }^{15}$ retrospectively investigated 2991 prostate cancer patients in the clinical T1 T2 stage. These patients were administered RP, brachytherapy, <72 Gy EBRT, $\geq 72$ Gy EBRT, and combined EBRT+brachytherapy. Neoadjuvant HT was applied to 622 patients for $\leq 6$ months, and no adjuvant therapy was administered after local treatment. Five- and seven-year BRFS rates with these treatments were similar, although outcomes in the $<72$ Gy EBRT group were considerable poorer relative to the other therapeutic modalities used. Schreiber et al. ${ }^{8}$ retrospectively investigated 720 patients receiving RP and RT. Patients in the RT arm received $\geq 7560$ cGy (7560-8100 cGy) RT. Analysis of six-year BRFS rates by risk groups revealed similar RT and RP outcomes in the low risk group, while outcomes in the RT arm were significantly better in the intermediate and high risk groups. Similar results were observed in our study, despite use of an RT dose of 70-74 Gy.

Taguchi et al. ${ }^{16}$ retrospectively investigated 891 T1 -T4NOMO patients receiving RP and RT in terms of clinical stages. Patients in the RT arm received a mean dose of 76 Gy RT. Five-year BRFS rates based on risk groups were significantly better in the RT arm than in the RP arm in all three risk groups, and the five-year OS was significantly better in the RP arm. Merino et al. ${ }^{17}$ retrospectively analyzed 1200 patients receiving RP and RT. Patients in the RT arm received a mean dose of 76 Gy RT. Five- and seven-year OS rates were similar in both arms in the low risk groups, while the rates were significantly better in the RP arm compared to the RT arm in the intermediate and high risk groups. In our study, although there was no difference between therapeutic modalities in terns of OS rates detected in risk groups, OS rates were higher in the RP arm than in the RT arm in all three risk groups. 
The success in BRFS with high-dose in RT was not achieved in terms of OS. In agreement with other studies $^{14,16,17,20-22}$, mean age at diagnosis in patients receiving RT in our study was significantly higher than that in patients receiving RP. Patients receiving RP were generally in the low and intermediate risk groups, and those undergoing RT were more populated in the high risk group. The greater age at diagnosis in the RT arm, the larger number of patients in the high risk group, and the presence of age-related comorbidities in these patients had a negative impact on the efficacy rate of the RT arm in terms of OS. The low risk group had the highest age at diagnosis in the RT arm in our study, and also the highest mortality rates Analysis of causes of death revealed that patients in the low risk group died from chronic diseases and other causes. Similar studies have also frequently reported deaths unrelated to prostate cancer among causes of death in the RT $\operatorname{arm}^{16,17,23,24}$.

\section{CONCLUSION}

Analysis of the effect of definitive RT on BR rates in patients with prostate cancer who were investigated retrospectively in this study revealed greater success rates in the high risk group in the RT arm,. despite its disadvantages as the relatively older age of the patients high rates of comorbid disease in that arm, in-homogeneously distributed patients, and lack of significant differences observed in BRFS and OS rates in terms of risk groups in the two arms. Further long-term studies involving high-dose RT techniques capable of providing maximum protection of normal tissues and confirming the effectiveness of RT are now needed. Extensive retrospective studies are needed due to the insufficiency of prospective studies comparing RP and RT performed in the context of current prostate cancer treatment in terms of survival.

\section{REFERENCES}

1. Mottet N, Bellmunt J, Bolla M, et al. EAU-ESTRO-SIOG Guidelines on Prostate Cancer. Part 1: Screening, Diagnosis, and Local Treatment with Curative Intent. Eur Urol. 2017;71:618-29. [CrossRef]

2. Jemal A, Bray F, Center MM, Ferlay J, Ward E, Forman D. Global cancer statistics. CA Cancer J Clin. 2011;61:69-90. [CrossRef]

3. Ferlay J, Soerjomataram I, Dikshit R, et al. Cancer incidence and mortality worldwide: sources, methods and major patterns in GLOBOCAN 2012. Int J Cancer. 2015;136:E359-86. [CrossRef]

4. http://www.who.int/cancer/country-profiles/tur_ en.pdf?ua=1. turkey cancer country profiles 2014

5. Beyzadeoglu M, Ozyigit G, Ebruli C. Basic Radiation Oncology. Berlin, Germany, Springer-Verlag, 2010. p. 36385. [CrossRef]

6. Hansen EK, Roach M III (Eds). Handbook of evidencebased radiation oncology. $2^{\text {nd }}$ Ed. Berlin, Germany, Springer International Publishing AG. 2010. p.431-78.

7. Cooperberg MR, Broering JM, Carroll PR. Time trends and local variation in primary treatment of localized prostate cancer. J Clin Oncol. 2010;28:1117-23. [CrossRef]

8. Schreiber D, Rineer J, Weiss JP, et al. Clinical and biochemical outcomes of men undergoing radical prostatectomy or radiation therapy for localized prostate cancer. Radiat Oncol J. 2015;33:21-8. [CrossRef]

9. Tewari A, Sooriakumaran P, Bloch DA, Seshadri-Kreaden U, Hebert AE, Wiklund P. Positive surgical margin and perioperative complication rates of primary surgical treatments for prostate cancer: a systematic review and metaanalysis comparing retropubic, laparoscopic, and robotic prostatectomy. Eur Urol. 2012; 62:1-15. [CrossRef]

10. Smit WG, Helle PA, van Putten WL, Wijnmaalen AJ, Seldenrath JJ, van der Werf-Messing $\mathrm{BH}$. Late radiation damage in prostate cancer patients treated by high dose external radiotherapy in relation to rectal dose. Int J Radiat Oncol Biol Phys. 1990;18:23-9. [CrossRef]

11. Smit WG, Helle PA, van Putten WL, Wijnmaalen AJ, Seldenrath JJ, van der Werf-Messing $\mathrm{BH}$. Late radiation damage in prostate cancer patients treated by high dose external radiotherapy in relation to rectal dose. Int J Radiat Oncol Biol Phys. 1990;18:23-9. [CrossRef]

12. Gunderson LL, Tepper JE. Clinical radiation oncology. $4^{\text {th }}$ Ed. Amsterdam, Netherlands, Elsevier; 2015. p. 1038-95.

13. D'Amico AV, Whittington R, Malkowicz SB, et al. Biochemical outcome after radical prostatectomy or external beam radiation therapy for patients with clinically localized prostate carcinoma in the prostate specific antigen era. Cancer. 2002;95:281-6. [CrossRef]

14. Aizer AA, Yu JB, Colberg JW, McKeon AM, Decker RH, Peschel RE. Radical prostatectomy vs. intensity-modulated radiation therapy in the management of localized prostate adenocarcinoma. Radiother Oncol. 200993:185-91. [CrossRef]

15. Kupelian PA, Potters L, Khuntia D, et al. Radical prostatectomy, external beam radiotherapy $<72 \mathrm{~Gy}$, external beam radiotherapy $>$ or $=72 \mathrm{~Gy}$, permanent seed implantation, or combined seeds/external beam radiotherapy for stage T1-T2 prostate cancer. Int J Radiat Oncol Biol Phys. 2004;58:25-33. [CrossRef]

16. Taguchi S, Fukuhara H, Shiraishi K, et al. Radical Prostatec- 
tomy versus External Beam Radiotherapy for cT1-4NOMO Prostate Cancer: Comparison of Patient Outcomes Including Mortality. PLoS One. 2015;10:e0141123. [CrossRef]

17. Merino T, San Francisco IF, Rojas PA, Bettoli P, Zúñiga A, Besa P. Intensity-modulated radiotherapy versus radical prostatectomy in patients with localized prostate cancer: long-term follow-up. BMC Cancer. 2013;13:530. [CrossRef]

18. Cookson MS, Aus G, Burnett AL, et al. Variation in the definition of biochemical recurrence in patients treated for localized prostate cancer: the American Urological Association Prostate Guidelines for Localized Prostate Cancer Update Panel report and recommendations for a standard in the reporting of surgical outcomes. J Urol. 2007; 177:540-5. [CrossRef]

19. Roach M 3rd, Hanks G, Thames H Jr, et al. Defining biochemical failure following radiotherapy with or without hormonal therapy in men with clinically localized prostate cancer: recommendations of the RTOG-ASTRO Phoenix Consensus Conference. Int J Radiat Oncol Biol Phys. 2006;65:965-74. [CrossRef]
20. Tamada S, Ninomiya N, Kitamoto $\mathrm{K}$, et al. Comparative effectiveness of radical prostatectomy and curative radiotherapy in localized prostate cancer: long-term followup. J Radiat Res. 2017;58:552-8. [CrossRef]

21. Gu X, Gao X, Cui M, et al. Survival outcomes of radical prostatectomy and external beam radiotherapy in clinically localized high-risk prostate cancer: a populationbased, propensity score matched study. Cancer Manag Res. 2018;10:1061-7. [CrossRef]

22. Serrell EC, Pitts D, Hayn M, Beaule L, Hansen MH, Sammon JD. Review of the comparative effectiveness of radical prostatectomy, radiation therapy, or expectant management of localized prostate cancer in registry data. Urol Oncol. 2018;36:183-92. [CrossRef]

23. Kim YJ, Cho KH, Pyo HR, et al. Radical prostatectomy versus external beam radiotherapy for localized prostate cancer: Comparison of treatment outcomes. Strahlenther Onkol. 2015;191:321-9. [CrossRef]

24. Rajan P, Sooriakumaran P, Nyberg T, et al. Effect of Comorbidity on Prostate Cancer-Specific Mortality: A Prospective Observational Study. J Clin Oncol. 2017;35:3566-74. [CrossRef] 